\title{
Pastoralist livelihoods and wildlife revenues in East Africa: a case for coexistence?
}

\author{
Katherine M Homewood ${ }^{1 *}$, Pippa Chenevix Trench $^{2}$ and Daniel Brockington ${ }^{3}$
}

\author{
* Correspondence: k.homewood@ \\ ucl.ac.uk \\ ${ }^{1}$ Anthropology, University College \\ London, Gower Street, London \\ WC1E 6BT, UK \\ Full list of author information is \\ available at the end of the article
}

\begin{abstract}
East African arid and semi-arid lands are home to many of the world's pastoralists and most spectacular savanna wildlife populations, attracting substantial conservation and tourism revenues. Yet these peoples are among the poorest (and most affected by extreme climatic events), and the wildlife is in unsustainable decline. National governments, international donors and conservation agencies favour win-win solutions through conservation with development. Maasailand is a hotspot of conservation, poverty and new initiatives to redistribute tourist income. We outline pastoralist livelihoods and how these are changing, then summarise status and trends of wildlife populations, tourism revenues, and conservation and development initiatives in East Africa and Maasailand. We ask to what extent wildlife revenues contribute to pastoralist livelihoods and whether this translates into a robust basis for coexistence. To put in context the role and importance of wildlife- and tourism-based activities, we outline findings from a multi-site study of Maasai livelihoods. Livestock contribute half or more of the mean annual income in all sites, with off-farm work and farming ranking second and third, respectively, except in Mara, where wildlife-based income contributes around 20\% income across all wealth categories. In most sites, significant areas have been set aside for conservation and tourism, but wildlife contributes $<5 \%$ income to a small proportion of households at most. Few wildlife-derived benefits flow to pastoralists, while conservation restrictions constrain production and coping strategies, undermining potential for coexistence. In exceptional circumstances, significant wildlife revenue may reach households, but full social and ecological implications of associated conservancy agreements remain unclear.
\end{abstract}

Keywords: East Africa, Maasai, Pastoralist, Wildlife, Livelihoods, Conservation, Tourism, Revenue, Ecological and economic sustainability

\section{Background}

East African arid and semi-arid lands (ASAL) are home to many of the world's pastoralists and most spectacular savanna wildlife populations, attracting substantial conservation and tourism revenues. Yet these peoples are among the poorest (and most affected by extreme climatic events), and wildlife is in unsustainable decline. National governments, international donors and conservation agencies favour win-win solutions through conservation with development. On the face of it, conditions appear favourable for pastoralists and wildlife to coexist in sustainable ways, with tourist revenues compensating for the livelihood impacts of any conservation restrictions. National governments, bilateral donors

\section{Springer}

(C) 2012 Homewood et al.; licensee Springer. This is an Open Access article distributed under the terms of the Creative Commons Attribution License (http://creativecommons.org/licenses/by/2.0), which permits unrestricted use, distribution, and reproduction in any medium, provided the original work is properly cited. 
and international conservation non-governmental organisations (NGOs) envisage such initiatives as partly or wholly replacing pastoralist livestock production, which has often been assumed to be environmentally damaging, with what are seen as more ecologically and economically sustainable wildlife-based forms of land use. Although there have been problems with transparency and accountability, in Maasailand there is a rapid proliferation of initiatives pursuing conservation with development, and these are fast evolving new institutions managing finances and monitoring enforcement and governance.

To put the contribution of wildlife tourism to poverty reduction and local livelihoods in context, we first outline pastoralist livelihoods and how these are changing, then summarise status and trends of wildlife populations, tourism revenues, and conservation and development initiatives in East Africa and Maasailand. This paper then asks to what extent wildlife revenues contribute to pastoralist livelihoods and whether this translates into a robust basis for coexistence. To do this, we look first at the role livestock and other activities play in rural Maasai household economies and in livelihoods overall. Recent analyses have cast households into four economic groups according to their position on the two axes of livestock holdings and cash income (McPeak et al. 2012). The studies we summarise here sought to capture a further dimension of livelihood strategies: the patterns of household-level diversification into different livelihood activities. Individual studies are reported in (Homewood et al. 2009). These studies sought a balanced and contextualised view of the contribution of wildlife conservation to local livelihoods in rural Maasailand by asking what were people doing, how well they did, what factors shaped choice of income-earning activities and what factors influenced how well they did. They explored whether identifiable livelihood strategies emerged in relation to particular predictors, and within any such strategies, looked for the significance of wildlife-related activities and income. Taking a comparative approach across Kenyan and Tanzanian study sites, these data allow evaluation of conservation and poverty reduction policies and practices.

We argue that rural Maasai land use decisions do not support national- and international-level assumptions about the benefits of wildlife and tourism, nor about a relatively lower economic importance of livestock production. However unequally distributed, and however insufficient in themselves to sustain families, livestock emerge as a vital part of rural and household economies. By contrast, wildlife revenues are sitedependent, of limited value for most areas and more vulnerable to elite capture.

\section{Pastoralist livelihoods in transition in sub-Saharan Africa}

The primary requirements for pastoralist production in ASAL are livestock, labour, and access to key grazing and water resources. Commonly favourable terms of trade for pastoral produce against grain make it possible for people to make a living selling milk or meat from even relatively low herd numbers (Swift 1986; Sikana et al. 1993). Despite long-term declines, and the effects of subsidised meat and milk products being dumped on African markets (e.g. The Economist 1993; Oxfam 2002), broadly favourable terms of trade still underpin successful pastoral economies (Zaal and Dietz 1999; Dietz et al. 2001; Zaal et al. 2006), although drought or epidemic can precipitate rapid collapse into famine (Homewood 2008). Physical remoteness from markets is often a major constraint (McPeak and Little 2006; McPeak et al. 2012), and transhumant movements may in part be dictated by market potential. Security issues, from periodic raiding to 
outright war, ${ }^{\mathrm{ii}}$ also constrain mobility, production and market access (Little 2003; McPeak and Little 2006, McPeak et al. 2012), as do disease and associated quarantine restrictions.

Within the pastoralist arena alone, there are numerous gender- and age-related livelihood activities around the pastoralist household enterprise, including animal husbandry, processing pastoral produce for home consumption or trade, livestock trade, politico-legal negotiation and physical enforcement of access to or exclusion from resources. Pastoralists almost always combine these livestock-focused occupations with complementary livelihood activities (Homewood 2008): farming, fishing, hunting and gathering, processing natural resources for sale, artisanal work, wage labour, salaried employment and/or investment in non-pastoral trade and businesses.

In East Africa, as elsewhere, pastoral areas including many Maasai communities in both Kenya and Tanzania continue to display wide and deep levels of poverty with respect to international and national rural poverty thresholds (Oxfam 2006; Kenya: Thornton et al. 2006, Boone et al. 2011; Tanzania: Tenga et al. 2008). Poverty is compounded by adverse policy and by biophysical disaster. As herd sizes per capita and range areas dwindle, as access to and movement between key resources become limiting and pastoralist options are more constrained, people increasingly depend on non-livestock elements of their multi-stranded livelihoods (Galvin 2009). Diversification of both poor and wealthy pastoralists may be into farming $c f$. (Mace 1993), but in ASALs, cropping is commonly so risky and yields so low that only the poorest derive much of their living from farming, with wage labour, remittances and trade (from petty vending to full-fledged businesses) often more salient sources of income (Homewood et al. 2009). Pastoralist diversification has tended to be treated as a special case (Little et al. 2001) but can be seen as a particular strand within the widely observed de-agrarianisation of African rural livelihoods (Bryceson and Jamal 1997). Households diversify through necessity, through risk management, and (for the most well-off) to build a portfolio of investment that goes well beyond, while still encompassing, pastoralist production and trade (Homewood et al. 2009). People, money and produce continually move between multi-local households. The rural part of the family may manage herds and crops in different sites with different agroecological potentials. Farming and livestock may operate as wealth store and investment for urban members' wages; meanwhile, rural households share farm produce with towndwelling kin (Homewood et al. 2009; see also Iliya and Swindell 1997). Town-based wage earners may send remittances, and host children attending school or sick people attending hospital. Some pastoralists are able to intensify, using supplements, veterinary inputs, fodder crops, tighter integration of farming and livestock, 'improved' high-yielding (but drought- and disease-prone) breeds and more market-oriented models of production. For example, better-off herd owners may buy up poorer families' young male calves and vaccinate them, enhancing survival and rearing a much higher proportion to commercially valuable size (Homewood et al. 2006).

What is the role of wildlife-based incomes in this complex tapestry of pastoralist livelihoods? Diversification and intensification mean increasingly sedentary life ways that allow access to farm work, jobs, markets, schools and hospitals, but impact adversely on livestock mobility, performance and production. Two crosscutting trends make pastoral production harder: land fragmentation (and land alienation) constraining mobility, and climate change, which is expected to make mobility even more crucial (Galvin 2009; Davies and Nori 2008). Alone among the many potential pathways 
of diversification outlined above, wildlife-based activities commonly promote more open rangelands theoretically consistent with mobile pastoralist production strategies. With wild grazers and domestic livestock depending on the same key resources, and pastoralists using mobility and migration strategies that closely parallel those whereby wildlife make the most of patchy and unpredictable grazing and water, there are synergies to be found. However, the overlap also potentially makes for competition and tradeoffs between wildlife and pastoralist land uses.

Tensions around tradeoffs are intensified by policy. Kenyan and Tanzanian governments see pastoralist livestock management (mobile transhumance on unfenced, unmodified rangelands) as unproductive and environmentally damaging e.g. (URT 1997; MoLF. 2006). Pastoral migration to south Tanzania is perceived, without good data, to be driven by pastoralists' own degradation of their rangelands (Brockington 2006). Regional and district governments impose draconian confiscations of cattle and fines, constraining pastoral activities while benefiting from their productivity. In contrast to the generally negative official take on mobile pastoralism, wildlife tourism is portrayed by these same agencies as an environmentally and economically sustainable means for pastoral groups to diversify, generate revenues and improve well-being. These schemes almost invariably aim for wildlife activities to replace pastoralism through a part of its range, and thus, for the two to coexist alongside one another, rather than overlapping fully within the same space (as was originally intended to be the case for multiple land use areas like the Ngorongoro Conservation Area, and as is envisaged for buffer zones around protected areas).

\section{Wildlife, tourism, conservation and development in East Africa}

Conservation is big business in East Africa. Tourism is regularly among the top three contributors to GDP and to foreign exchange earnings in Kenya, accounting for USD 884 million in 2010 Kshs 73.7 billion; (Ministry of Tourism 2010). Despite the global financial crisis, Tanzania earned USD 1.16 billion from tourism in 2009 (The Tanzania National Website 2009). In both countries, tourists are strongly drawn by the appeal of wildlife alongside other attractions. Conservationists see tourists' dollars as one of the principal means to generate meaningful income for the rural poor (Roe et al. in press). Government policies (URT 2002, 2005; UNDP/UNEP/IIED/IUCN/WRI 2005), conservation NGO projects (AWF 2005), entrepreneurial initiatives (Nelson 2004; Lewa Wildlife Conservancy 2010) and research publications (Pearce and Moran 1994; Hutton et al. 2005) all promote wildlife-based tourism. Maasailand, the region of Kenya and Tanzania dominated by Maa-speaking pastoralists, is a hotspot of conservation, poverty and new initiatives to redistribute tourist income and is a good place to explore dynamics and distribution of revenues.

In Kenya, Maasailand and other pastoral areas represent among the fastest growing tourism destinations (33\% growth in bed-nights 2004 to 2005; Ministry of Tourism and Wildlife 2006). In Tanzania in 2009, 16 National Parks earned USD 43.8 million; Ngorongoro Conservation Area, USD 22.6 million; and tourist hunting, USD 14.9 million (The Tanzania National Website 2009). In both Kenya and Tanzania, the highest earning protected areas are situated within, and effectively excised from, Maasailand (Figure 1), as is a high proportion of the two countries' conservation estate overall. Parts of Kenyan Maasailand have shown rapid economic growth driven by 


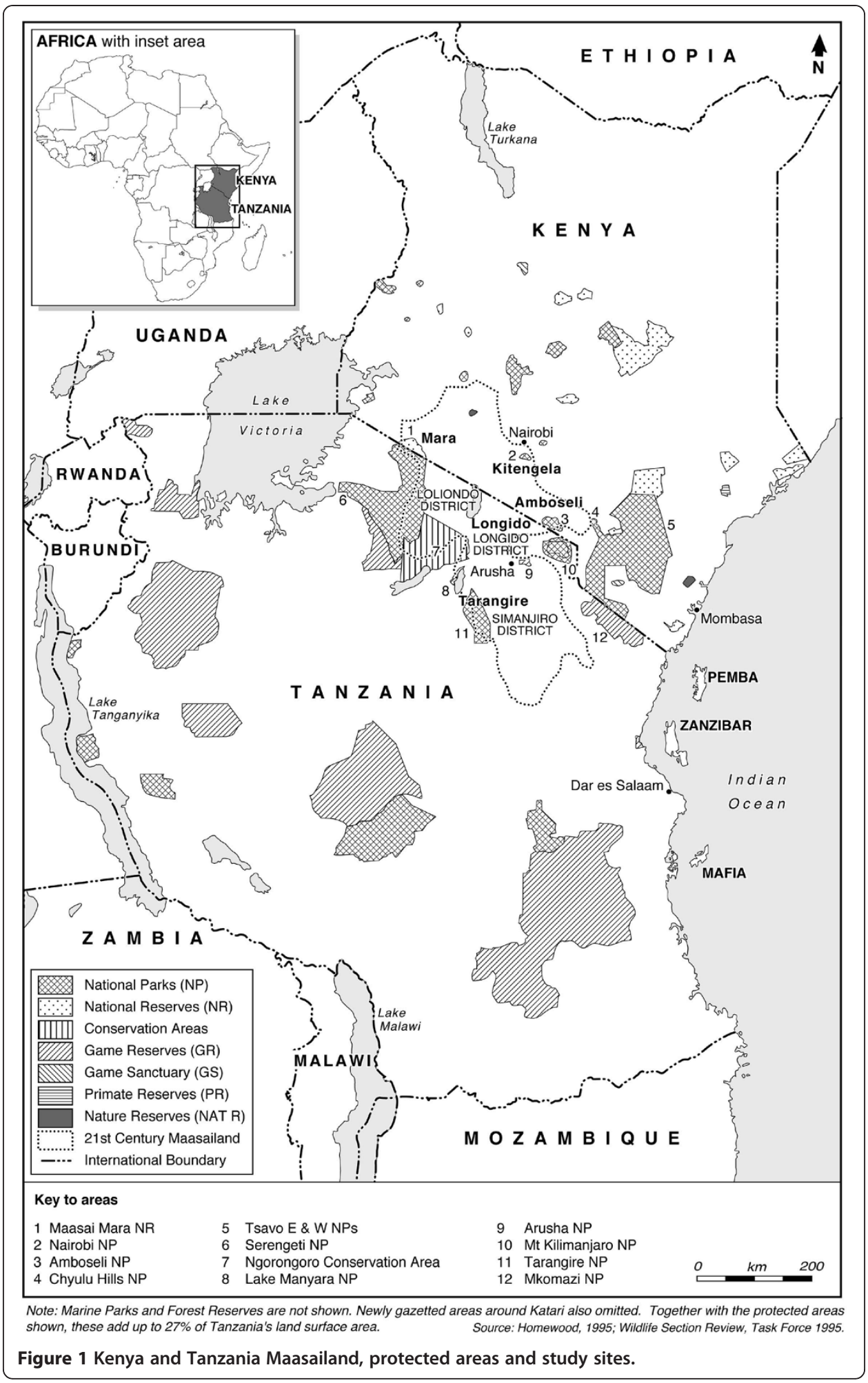

wildlife conservation, rising domestic and export markets for crops and rising land values (Norton-Griffiths and Said 2010).

However, the wildlife populations are in drastic and well-documented decline. Kenya's long-term aerial count datasets show that there has been a $50 \%$ to $80 \%$ decline in 
numbers of the vast majority of wildlife species since counts began in the mid-1970s (Ottichilo et al 2001; Homewood et al. 2001; Western et al. 2006, 2009; Ogutu et al. 2011). This decline is as marked within as around protected areas (Western et al. 2006). Though data for other East African regions are less complete, and declines seem less apparent in Tanzania (Homewood et al. 2001), similar trends are emerging (Sinclair et al. 2008). For example, Stoner et al. (2007) collated 1980s to early 2000s aerial census data for large herbivore populations in eight large census zones in Tanzania. Of those that showed significant changes, most declined. Thomson's gazelle, Grant's gazelle, hartebeest, reedbuck, roan antelope, sable antelope, warthog and zebra declined in over $50 \%$ of the zones where they were surveyed, though elephant and giraffe generally fared well across the country. Around Tarangire, elephants are increasing, while wildebeest are declining (Sachedina 2008).

These declines have taken place despite heavy investment in wildlife management and conservation by governments and international conservation NGOs (Norton-Griffiths 2007; Scholfield and Brockington 2009). There are a number of possible causes of wildlife decline, which can be categorised using Diamond's 'evil quartet' of factors driving species extinctions. These are habitat loss, introduced species (including disease), overhunting (by human or non-human predators) and secondary extinctions (following the prior extinction of organisms on which the species under consideration depends). In the case of East African wildlife, each of these factors has been shown to apply to some extent for individual species in individual sites. For example, in Serengeti and Ngorongoro, temporary local extinction of wild dog and a drastic decline in lion populations were both caused by an outbreak of canine distemper (Sinclair et al. 2008, page 3). Across Africa, rhinoceros are perennially vulnerable to illegal hunting. Some rhino subspecies are thought to be locally extinct in a number of sites, and others have been hunted to near-complete or complete regional extinction across East Africa (Sinclair et al. 2008), page 39; (Milliken et al. 2009). On Laikipia Plateau in Kenya, predator increases associated with private conservancies and their interplay with livestock ranching are thought to have driven down wild herbivore numbers in ways that impact unevenly across numerically dominant as opposed to relatively less numerous species (Georgiadis et al. 2007). More generally, decades of ecological research have shown that forage scarcity, predator pressure, outbreaks of disease and other factors acting whether singly or in concert have all limited the populations of individual East African savannah herbivores (Sinclair et al. 2008). However, both at the global level (Lambin and Meyfroidt 2011; Mace et al. 2005) and more specifically in Kenyan and other East African rangelands (Western et al. 2009), habitat loss is increasingly emerging as the most salient cause of species decline. The marked synchronous decline of regional populations of over 40 large mammal East African savanna species between 1975 and the present day, while exacerbated by the interplay of numerous individual factors, is likely to be driven primarily, though not exclusively, by loss of habitat through land fragmentation and conversion to cultivation. Species decline across the board around Mara, and across Kenya more generally (Western et al. 2009), has been linked to proliferation of large-scale commercial cultivation on the one hand (Homewood et al. 2001), and of smallholdings on the other (Lamprey and Reid 2004), along with subdivision and fencing off of private plots within formerly communal open rangelands (Nkedianye et al. 2009). These changes make it increasingly difficult for wildlife, 
as well as livestock, to access grazing and water, and to move between key dry and wet season resources.

Economic analyses suggest that the relatively poor contribution of wildlife to landowner-entrepreneurs and the considerably greater returns per unit area from commercial crops influence choices to convert land to large-scale cultivation (Norton-Griffiths et al. 2008; Norton-Griffiths and Said 2010). Around Mara, households making the most from conservation revenues were also those investing most in commercial cultivation in ways not compatible with sustainable conservation (Thompson et al. 2002). Besides owner-entrepreneurs, nation states such as Ethiopia, Kenya and Tanzania are increasingly leasing very extensive areas of rangelands to foreign entrepreneurs and states for largescale cultivation of biofuels and food crops for export (Zoomers 2010), suggesting that for these states, the returns from leasing out rangelands for cultivation outweigh the combined use values and intrinsic values of wildlife.

Similar considerations may be just as important in local smallholders' livelihoods choices. However, as well as direct economic benefits, land conversion is also driven by the local people's strategies for securing what is otherwise weak land tenure in rangelands. This is because rangelands may constitute key seasonal grazing areas but are seen by states as unproductive and unused, and therefore as available for alienation (Sachedina 2008; Thompson and Homewood 2002; Thompson et al. 2009). As well as economic and tenure strategies, people have taken up cultivation because of state pressure to grow crops, with countries such as Tanzania holding up farming (and the land conversion that inevitably accompanies it) as a national ideal, continually emphasised through the school system and the media (Bishop 2007).

Given the evidence for habitat loss as driver of species decline and for the salience of economic incentives encouraging land conversion, we ask to what extent wildlife revenues contribute to pastoralist livelihoods and whether this translates into a robust basis for coexistence. To put the role and importance of wildlife- and tourism-based activities into context, we outline and draw upon findings from a multi-site study of livelihoods in Kenya and Tanzania Maasailand for detail of methods, (see Serneels et al. 2009, and individual case study sites in Homewood et al. 2009). The analysis we present below of pastoralist livelihoods around protected areas is a step towards exploring how conservation needs and pastoral goals might be reconciled, and coexistence made a more sustainable possibility.

\section{Study area}

Maasailand is a loosely defined area of some $150,000 \mathrm{~km}^{2}$ of mostly arid and semi-arid rangeland straddling the Kenya/Tanzania border in East Africa (Figure 1). The rural areas are dominated by Maa-speaking agropastoralists and pastoralists, though increasingly large urban areas (Nairobi, Arusha, Moshi, Monduli, Narok) attract considerable inmigration from across the region and internationally. An overall rainfall gradient from the dry southeast in Tanzania (500 mm/year) to the wet northwest in Kenya (1,200 mm/year), combined with the Rift Valley topography and the influence of Lake Victoria, generate a diversity of local climates, with comparable growing conditions and vegetation types repeated across different land use zones and on both sides of the border. These range from seasonally very productive short-grass associations such as those which characterise the Serengeti Plains (and prior to conversion, the Loita Plains in Kenya) to taller stands of 
grass in wetter areas, grading into bushland, thicket and Acacia woodland. Some areas in the Ngorongoro Crater Highlands and the Mau Escarpment carry montane forest, and there is gallery forest along the Mara River. In addition to these vegetation formations, land cover includes increasing areas of cultivation, ranging from hand- or ox-based smallholder farming to broad stretches of mechanised, commercial systems. Many different state, community-based and private conservation initiatives exist across the area; these vary in approach, levels of community participation, and in type and scale of potential returns to different stakeholders. The international border bisecting Maasailand creates parallel zones of different land-use and conservation orientations linked to the different policies and conditions existing in the two countries: Kenya has private land ownership, relatively developed transport and market infrastructure, and a strong private enterprise ethos, whereas Tanzania has state ownership alongside customary management of land, poorly developed transport, poor market access and an economy that is still largely centrally controlled.

This paper makes a synthesis of findings from multisite studies of Maasai livelihoods, drawing on work by independent researchers ${ }^{\mathrm{i}}$ studying three Kenyan and two Tanzanian sites (Table 1, Figure 2; Homewood et al. 2009). Each site constitutes a population of Maasai living near a conservation area (Table 2). The five sites (Tables 1 and 2, Figure 2) represent very different circumstances and opportunities for diversifying, ranging from communities around high-earning conservation areas (Mara: Thompson et al. 2009), to low- (or no-) earning wildlife management areas (Longido: Chenevix Trench et al. 2009). They spanned remote rural areas dominated by herding and farming activities (Amboseli: BurnSilver 2009; Longido: Chenevix Trench et al. 2009) to areas with commercial cultivation and mining (Tarangire: Sachedina and Chenevix Trench 2009), to peri-urban sites (Kitengela: Nkedianye et al. 2009) where land leasing, marketing produce and off/non-farm employment are important income streams (Table 2).

\section{Methods}

The data and comparative analyses outlined here build upon published standardised income and explanatory variables which were collected or derived for each of the study sites during the period 2004 to 2006 by independent researchers ${ }^{\mathrm{i}}$ and their teams, according to standardised definitions and approaches as agreed during the DGIC-funded Reto-o-Reto project (Serneels et al. 2009). Those data were based upon household surveys, with sampling which used wealth ranking and, in some cases, stratification of households by spatial location. In total, over 1,000 households were surveyed (Table 1) representing a broad cross-section of Maasai in pastoral rangelands. Our interpretation and analysis also draw upon published cluster analyses which identified groups of households with similar patterns of activities in each area and regression analyses which identified significant factors explaining variation in income levels across households (Serneels et al. 2009). Our analysis and interpretation also incorporate insights from published family portrait studies which captured qualitative, household-level pictures of livelihoods and livelihood change (Homewood et al. 2009).

\section{Results and discussion}

Great variability in livelihood strategies and in wealth was expected (and found) both within and between sites. Briefly, each site had a cluster of livelihood strategies corresponding to households which were primarily dependant on pastoralism ( $c f$. households 
Table 1 Five study sites across Kenya and Tanzania Maasailand

\begin{tabular}{|c|c|c|c|c|c|c|c|}
\hline Site & $\begin{array}{l}\text { Area } \\
\left(\mathrm{km}^{2}\right)\end{array}$ & $\begin{array}{l}\text { Rain } \\
\text { (mm/pa) }\end{array}$ & $\begin{array}{l}\text { Number of } \\
\text { hh in sample }\end{array}$ & $\begin{array}{l}\mathrm{AE} / \\
\mathrm{hh}\end{array}$ & $\begin{array}{l}\mathrm{TLU} / \\
\mathrm{AE}\end{array}$ & $\begin{array}{l}\text { Livestock ownership } \\
\text { by wealth }\end{array}$ & Reference \\
\hline Mara & 6,500 & $\begin{array}{l}400 \text { to } \\
1,200\end{array}$ & 219 & 7.4 & 13 & $\begin{array}{l}\text { Top } 25 \% \text { own } 58 \% \\
\text { TLU (1998) (dropping } \\
\text { to } 36 \% \text { in 2004) }\end{array}$ & $\begin{array}{l}\text { Thompson et al. } \\
2009\end{array}$ \\
\hline Kitengela & 390 & $<600$ & 177 & 4 & 7.2 & $\begin{array}{l}\text { Top 20\% own } \\
47 \% \text { TLUs }\end{array}$ & $\begin{array}{l}\text { Nkedianye et al. } \\
2009\end{array}$ \\
\hline Amboseli & 8,400 & $\begin{array}{l}350 \text { to } \\
600\end{array}$ & 184 & 8.9 & 6.3 & $\begin{array}{l}\text { Top 10\% own } \\
45 \% \text { TLU }\end{array}$ & BurnSilver 2009 \\
\hline Longido & 9,220 & $\begin{array}{l}300 \text { to } \\
600\end{array}$ & 229 & 8.9 & 4.2 & $\begin{array}{l}\text { Top 7\% own } \\
50 \% \text { TLU }\end{array}$ & $\begin{array}{l}\text { Chenevix Trench } \\
\text { et al. } 2009\end{array}$ \\
\hline Tarangire & 22,200 & 650 & $194^{\mathrm{a}}$ & 5.7 & 3.8 & $\begin{array}{l}\text { Top 20\% own } \\
66 \% \text { TLUs }\end{array}$ & $\begin{array}{l}\text { Sachedina and } \\
\text { Chenevix Trench } 2009\end{array}$ \\
\hline
\end{tabular}

Hh Household, $A E$ adult equivalent, $T L U$ tropical livestock unit. For technical definitions, see Sellen 2003. ${ }^{a}$ In Tarangire, a sub-sample of $37 \mathrm{hh}$ was studied in depth; 27 of these were also included in the broad-scale survey: livestock figures are derived from these.

'staying' as primarily pastoralist; McPeak et al. 2012). Beyond this, each site showed a different array of clusters or livelihood strategies representing different combinations of activities in different relative proportions dictated by local circumstances and opportunities. This great variability is summarised here under livestock, farming, off-farm employment and wildlife-related activities.

Livestock

Pastoral production accounted for well over half of the mean income for the pooled samples in each site (Figure 1). While most (91\% to 100\%) households had livestock, a significant proportion in each site had too few to support household members fully. Most animals were concentrated in the hands of a few, with the top $10 \%$ to $20 \%$ households owning half to two-thirds of all livestock across all sites (Table 1).

Reliance on non-livestock income was therefore a necessity for most, especially for the poorest, quite apart from being a potentially positive investment option for the well-off. Nonetheless, in each site, across all different wealth categories and across most livelihood strategies, people were actively purchasing livestock. Poor households continued to seek to rebuild their herds, while better-off households continued to invest in new animals.

\section{Farming}

Farming was widely practised. Maasailand is mostly semi-arid, and most households had limited access to agro-ecologically favourable sites. In four out of the five study areas, $>50 \%$ of households farmed (Kitengela 68\%, Amboseli 57\%, Longido 67\%, Tarangire 88\%; see Figure 2). In Mara, only $13 \%$ households cultivated.

However, yields were generally poor and contributed little to overall incomes. In Mara, Longido and Kitengela, $>50 \%$ of the households that farmed harvested nothing. Amboseli yields were variable; again, many households failed to harvest. Crops accounted for just $2 \%$ of the mean total income in Mara, $8 \%$ in Kitengela, $12 \%$ in Tarangire, $14 \%$ in Amboseli and $21 \%$ in the poorest site, Longido.

Farming contributed to livelihood security on several levels. In addition to the benefits for food security and opportunities for commercial cropping in some sites (Mara, Tarangire), cultivation has been an effective means of staking claim during land privatisation and subdivision e.g. Kenya, Mara; (Thompson et al. 2009), and 


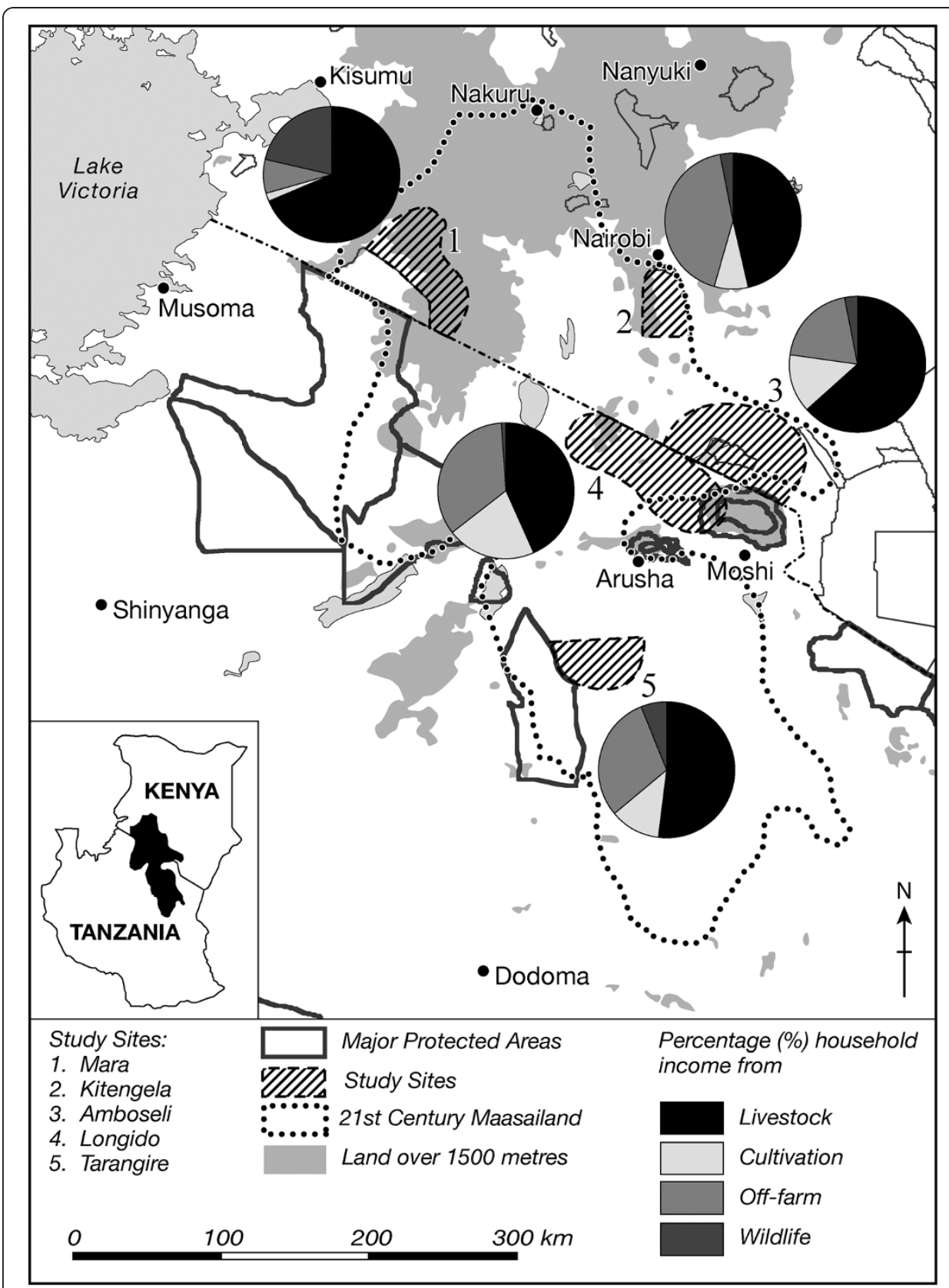

Figure 2 Five study sites and mean proportional composition of household income in each case.

countering protected area expansion e.g. Tanzania, Tarangire; (Sachedina and Chenevix Trench 2009).

Both direct observation and remotely sensed land cover analyses showed extensive large-scale commercial cereal cultivation in the outer ring of former group ranches around the Maasai Mara National Reserve (MMNR). However, both the proportion of households involved in commercial cultivation and its total acreage dropped significantly between 1998 and 2004 with the completion of land titling across most of the area studied and more recently with the rise of conservancy agreements across the former group ranches immediately adjacent to MMNR (Bedelian in press). Alongside 
Table 2 Context of wildlife-related and other income streams

\begin{tabular}{|c|c|c|c|c|}
\hline Site & Protected area & $\begin{array}{l}\text { Conservation/ eco- } \\
\text { tourism project }\end{array}$ & Non-farm & Crop and livestock \\
\hline Mara & $\begin{array}{l}\text { Maasai Mara NR } \\
\text { earns } \$ 15 \text { to } \$ 20 \\
\text { million pa }\end{array}$ & $\begin{array}{l}\text { Numerous conservancy/ } \\
\text { WA/tourism operations; } \\
64 \% \text { of hh earn from } \\
\text { wildlife, which averages } \\
>20 \% \text { mean annual income }\end{array}$ & & $\begin{array}{l}\text { Richest site in livestock; } \\
\text { commercial cultivation/ } \\
\text { land leasing declining }\end{array}$ \\
\hline \multirow[t]{2}{*}{ Kitengela } & \multirow[t]{2}{*}{ Nairobi NP } & \multirow{2}{*}{$\begin{array}{l}\text { KILA operates leaseback to } \\
\text { keep rangeland unfenced; } \\
14 \% \text { of hh get ca } 3 \% \text { mean } \\
\text { income this way }\end{array}$} & $\begin{array}{l}\text { Urban effect: Land } \\
\text { values }>\text { Kshs } \\
\text { 100,000/acre }\end{array}$ & \multirow{2}{*}{$\begin{array}{l}\text { Off farm opportunities; } \\
\text { urban market for milk } \\
\text { ( } 1 / 3 \text { livestock-related } \\
\text { income) and crops }\end{array}$} \\
\hline & & & $\begin{array}{l}\text { Population times } 2.5 \\
\text { from } 1989 \text { to } 1999\end{array}$ & \\
\hline Amboseli & Amboseli NP/NR & $\begin{array}{l}\text { Numerous small tourism } \\
\text { operations bring little to } \\
\text { outer, drier group ranches }\end{array}$ & & $\begin{array}{l}\text { Wetlands converted to } \\
\text { intensive production; } \\
\text { dry land cropping is } \\
\text { risky }\end{array}$ \\
\hline \multirow[t]{2}{*}{ Longido } & \multirow{2}{*}{$\begin{array}{l}\text { None, but ringed by } \\
\text { protected areas }\end{array}$} & \multirow{2}{*}{$\begin{array}{l}\text { Enduimet WMA sets aside } \\
\text { majority of land for seven } \\
\text { villages: State captures } \\
\text { returns, negligible } \\
\text { trickledown }\end{array}$} & \multirow{2}{*}{$\begin{array}{l}\text { Poorer hh rely on } \\
\text { (limited) wage } \\
\text { opportunities for } \\
\text { food and to rebuild } \\
\text { herds }\end{array}$} & Poorest site \\
\hline & & & & $\begin{array}{l}\text { Farming essential; } \\
\text { livestock are few but } \\
\text { central }\end{array}$ \\
\hline \multirow[t]{2}{*}{ Tarangire } & \multirow{2}{*}{$\begin{array}{l}\text { Tarangire and } \\
\text { Manyara NPs }=13 \% \\
\text { area; } \$ 4.5 \text { million pa } \\
\text { gate fees, \$0.5 } \\
\text { million hunting } \\
\text { revenues }\end{array}$} & $\begin{array}{l}\text { Emboreet CBC; Manyara } \\
\text { Ranch }\end{array}$ & \multirow{2}{*}{$\begin{array}{l}35 \% \text { of hh get } \\
\text { mining-related } \\
\text { remittances; } 45 \% \\
\text { respondents have } \\
\text { been involved in } \\
\text { mining }\end{array}$} & \multirow{2}{*}{$\begin{array}{l}\text { Mechanised maize } \\
\text { cultivation initially } \\
\text { tenure strategy, now for } \\
\text { commercial profit }\end{array}$} \\
\hline & & $\begin{array}{l}\text { Ongoing conflict: } \\
\text { Sachedina (2008) }\end{array}$ & & \\
\hline
\end{tabular}

CBC community-based conservation, $h$ h household, KILA Kitengela landowners' association, NP national park, NR national reserve, TLU Tropical livestock unit, WA wildlife association (Kenya), WMA wildlife management area (Tanzania).

poor rainfall and declining soil fertility, the transaction costs of dealing with multiple smallholders (as opposed to dealing with the group ranch committee for large areas) made large-scale farming in Kenya Maasailand difficult.

Large-scale cereal farming had also spread around Tarangire. Maize cultivation was a lucrative possibility for households able to invest in mechanised farming (Sachedina 2008). However, opportunities for such large-scale farming were not widespread elsewhere. In the poorest site, Longido, with the highest proportion of households farming, former village-owned high-potential lands on the slopes of Mt. Kilimanjaro (east of Longido town) had long since been leased by the state to outside investors (Chenevix Trench et al. 2009).

\section{Off-farm activities}

Half or more households ( $50 \%$ to $85 \%$ ) earned off-farm income from petty trade, business, wages or salaried income and remittances (Figure 2). Returns from casual unskilled work are a fraction of those for regular jobs as teacher, driver or government official. Potentially large but ephemeral income streams from gemstone mining and brokerage, and land leasing, tended to be seen as secondary in importance to livestock and other economic activities. Off-farm work accounted on average for 8\% Mara, 20\% Amboseli, 30\% Tarangire, $34 \%$ Longido and 43\% Kitengela income - second only to livestock in most sites, other than Mara (Figure 2). Earnings from off-farm work are particularly salient in two sites: the poorest site Longido (where the poorest households depend entirely on off-farm income or remittances; Figure 3) and peri-urban Kitengela, where there are increased opportunities for such work. This bears out analyses emphasising the need for off-land work and 
the willingness of pastoral peoples to pursue these activities e.g. Sandford 2006; Boku 2008; Galvin 2009; McPeak et al. 2012).

\section{Wildlife-related income}

There are wildlife-based initiatives in all sites and in most cases, established protected areas too (Table 2). In principle, there are multiple channels whereby local people may derive income from wildlife-related activities. These divide into returns at community level and those which come direct to the household or individual. Possible wildliferelated income streams differ between Kenya and Tanzania, and between different sites within countries.

In Kenya, MMNR gate fees flow to the Narok County Council with a proportion translating into community development. In some sites, a proportion of gate fees earned by other protected areas (national parks, Ngorongoro Conservation Area) are also said to be channelled to community development (but often with little transparency or accountability; see e.g. Sinclair et al. 2008, pages 452 to 454). Returns at the community level are supposed to translate into improvements in health, education, transport and other community facilities though they may be dissipated through poor central, districtor community-level governance, elite capture or outright corruption (Thompson and Homewood 2002; Sachedina 2008). In some cases, tour companies pay contractors directly to carry out village-approved improvements (Sachedina and Chenevix Trench 2009). In both Kenyan and Tanzanian sites, some individuals received bursaries for education or medical treatment either through community board decisions (Thompson and Homewood 2002) or direct from tour operators (Sachedina and Chenevix Trench 2009).

However, with land privatisation around Mara and Kitengela in Kenya, former community-based organisations (e.g. wildlife associations formerly congruent with group ranches around Mara) have largely ceased to function. Instead, they have given way to one-on-one, standardized land lease deals between individual landowners and conservancy enterprises around Mara, and conservation easements around Kitengela. Some landowners have privately owned tourist campsites on their land (Thompson et al. 2009).

In Tanzania, bed-night payments, concession fees and contributions from game viewing or hunting companies could originally be paid directly into village accounts for social development projects, but the new regulations for wildlife management areas (WMAs) mean that these monies are intercepted at the level of central government (Sachedina and Chenevix Trench 2009). Wildlife-related income has in the past been used on occasion at village level to offset cesses (village-level taxes) in Tanzania. This created positive but arguably invisible impacts on household income, in that these community-level effects are not captured by household survey. However, where data were available, it was clear that village-level benefits were easily captured by local elites and were not having the broader impacts on livelihoods that could influence household decision-making in favour of conservation-compatible land use (Sachedina 2008; Nelson et al. 2009). ${ }^{\text {ii }}$

Household surveys in all sites focused on income streams coming to individuals within the household. Wildlife-related income was recorded to include activities that would otherwise be categorised as returns from business or salaries but which would not be available as opportunities without the wildlife (Serneels et al. 2009). Some individuals secured employment as labourers or guides e.g. (Sachedina and Chenevix Trench 2009), as community scouts monitoring set-aside areas (e.g. Kitengela; Nkedianye et al. 2009), 


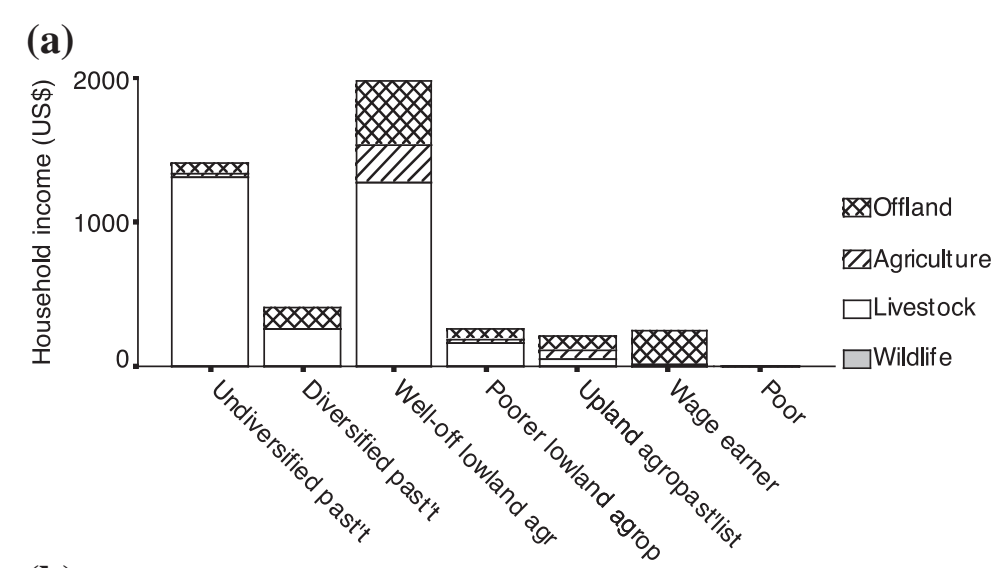

(b)

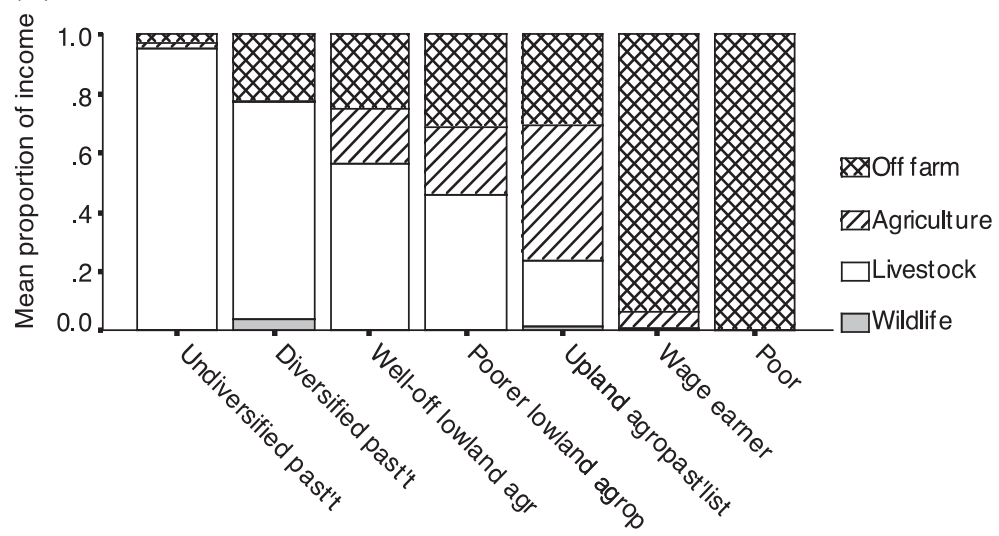

Figure 3 Livelihood strategies in Longido. (a) Different strategies are represented according to annual household income from livestock, agriculture, conservation and off-farm sources. The first bar of the chart represents undiversified pastoralists; the others have significant proportional contributions from other activities. Some households ('poor') had no source of income or production, other than remittances from absent members. (b) Same data represented as proportions of mean total income for each strategy. Note that most have no wildlife-based income, but only the poorest have no livestock.

and as Kenya Wildlife Service rangers (Thompson and Homewood 2002; Thompson et al. 2009). Some individuals derived income from tourist-oriented activities, such as cultural boma performances, sales of beadwork, jewellery and other craftwork. In at least one site, some villagers had received payment for facilitating illegal hunting, though such activities could not be systematically researched through household survey.

To summarise, compared with the universal engagement with livestock and the widespread involvement with farming and off-farm work, only a small proportion of households received wildlife earnings in most sites (3\% to 14\%). Averaging across those households which do derive income from wildlife, amounts were small in most sites, contributing $<5 \%$ of the mean annual income (Figure 2).

While overall few Maasai households earn from wildlife, and the sums they make do not compare with main income streams from livestock, crops and off-farm sources, landowning households close to the MMNR saw real benefits from conservation-based enterprises. In contrast to the other sites, two-thirds (64\%) of the households in Mara earned some income from wildlife, and wildlife conservation accounted for $21 \%$ of the mean annual income for Mara households in the sample (Figures 2 and 4). This is explored in more detail in the next section. 

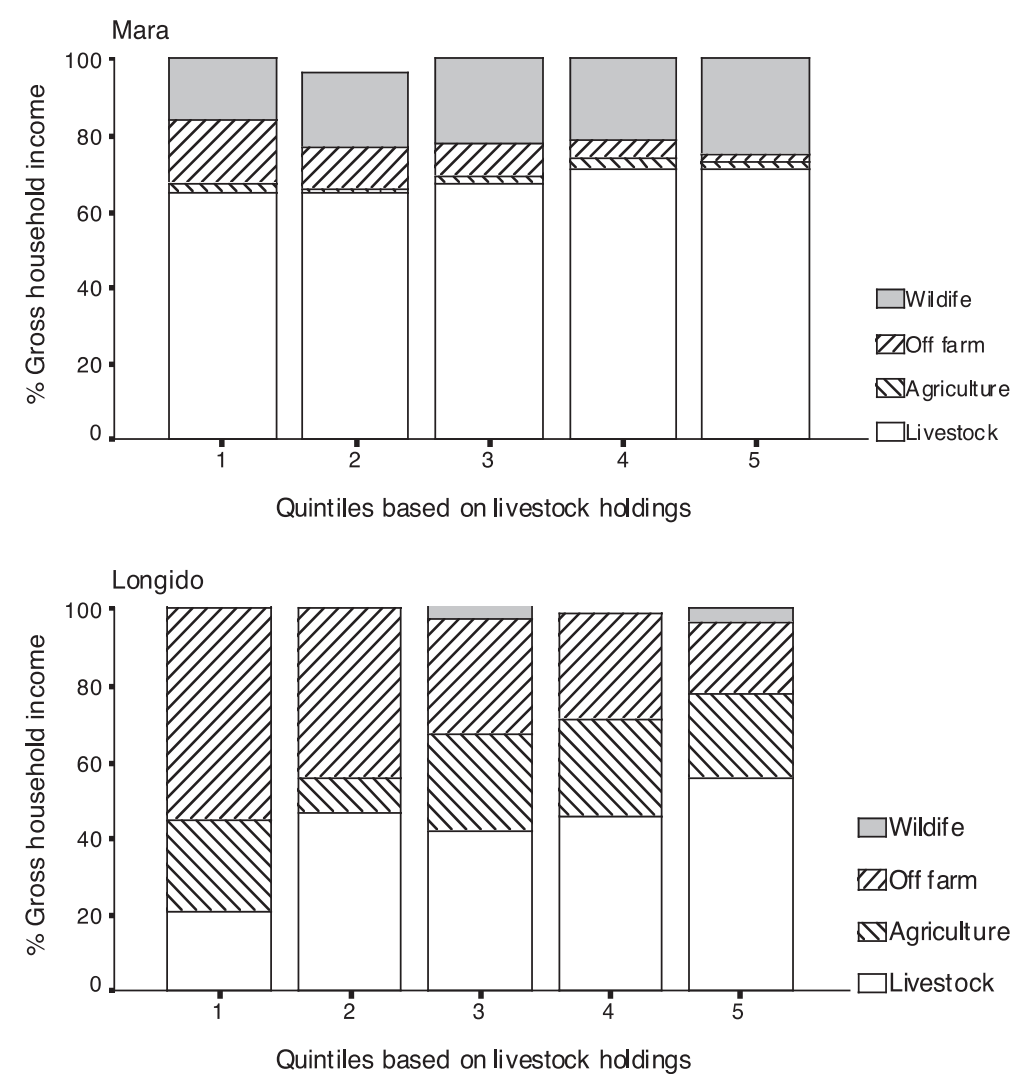

Figure 4 Relative importance of different income sources across different wealth quintiles for households. (a) Mara and (b) Longido households; ( 1 = poorest/least livestock, $5=$ most livestock).

\section{Conservation, wealth and poverty in Mara}

MMNR is Kenya's highest-earning wildlife tourist destination, taking 15 to 20 million USD annually (Norton-Griffiths 2007). Numerous additional wildlife enterprises have grown up around Mara, with landowners ${ }^{\text {iv }}$ on the now-adjudicated, subdivided and privately owned former group ranch lands able to capture wildlife returns. There has been a rapid evolution of revenue-sharing institutions around Mara since the 1970s, from the initial 19\% county council MMNR gate takings paid to group ranch wildlife associations; through post-group ranch, politically constituted wildlife associations; and most recently, conservancy partnerships between tourism investors and landowners (Thompson et al. 2009; Bedelian in press). The most recent conservancy agreements offer better security of income to landowners, through rent rather than bed-night payments. They require 5- to 15-year covenanting of the designated area, during which current resident households must move out. In covenanted areas, land sales, homestead construction, cultivation and fencing are excluded, as is grazing of livestock under most circumstances (Bedelian in press). Conservancy arrangements may offer a better deal for landowners (Thompson et al. 2009) and better conservation outcomes (Western et al. 2006). They remain to be evaluated in terms of implications for wildlife populations (Western et al. 2009), impacts on households forced to move by conservancy restrictions (particularly those relocating herds, and those who are non-landowners and who therefore receive no compensatory revenues), and impacts on receiving areas (Bedelian in press). 
In Mara, wildlife revenue made up $15 \%$ to $30 \%$ of the mean household income across the wealth spectrum from the poorest quintiles to the best-off (Figure 4), second in importance only to livestock. However, the top 25\% of Mara households by wealth consistently captured $60 \%$ to $70 \%$ of conservation income. The bottom $25 \%$, by contrast, captured around 5\%, rising to $15 \%$ if all forms of associated conservation-related employment are included. The middle $50 \%$ took around $25 \%$ of conservation-related income across the board. Despite significant changes in the volume of tourism returns between 1998 and 2004, there was minimal change in this pattern of distribution across wealth ranks. The poorest $20 \%$ of households were consistently more likely to be engaged in cultivation and/or off-farm work and significantly less likely to receive wildlife income than other households (Thompson et al. 2009).

The total volume of tourism returns in Kenya fell significantly between 1998 and 2004, probably as a result of the impact on tourism internationally of the attacks on the World Trade Center in New York in 2001. Tourism collapsed again in 2007 to 2008 following Kenya's post-election violence. In the pre-conservancy era 2004 Mara surveys, mean conservation incomes to households earning from what were then wildlife associations and campsites averaged just 25\% of their 1998 value. Within that changing flow of revenue, the relative proportions captured by the wealthiest, middle and poorest Mara households stayed remarkably constant. However, between 1998 and 2004, proportions of households receiving income from wildlife associations fell from $55 \%$ to $37 \%$. Overall, the proportion of households reporting income from the wildlife associations and campsites (which were the main wildlife-based initiatives at the time) dropped from $55 \%$ to $41 \%$.

Despite inequalities, conservation earnings reached most households in the Mara sample, and returns at household level, while very variable, on average, made a significant contribution. However, comparison of Mara with the four other sites suggests that these benefits are linked to conditions rarely met elsewhere. MMNR is high-earning compared with other tourism destinations. The households sampled are predominantly those of present landowners situated close to the MMNR, who are able to command pay for game viewing or accommodation on their land. ${ }^{\mathrm{v}}$ By contrast, households elsewhere that are remote from tourist attractions or near lower-earning sites, or do not own land, are less able to compete for conservation jobs or have little access to wildlife income overall. This applies to the outer Amboseli households (BurnSilver 2009); those close to Amboseli National Park reportedly earn significantly more, possibly comparable to those in Mara (Western, personal communication). In the poorest site, Longido, livestock remain the most important livelihood. Additional income streams are dominated by returns from off farm and farming, while wildlife revenues are minimal and poorly distributed across the wealth spectrum (Chenevix Trench et al. 2009; Figures 2 and 3b).

\section{Conclusions}

These findings underline the lasting, central importance of livestock to livelihoods across Maasailand. As for other studies (Boku 2008), livestock holdings represent the single strongest measure or indicator of other dimensions of wealth in all sites. ${ }^{\mathrm{vi}}$ By contrast, they emphasise both the generally limited contribution of wildlife and conservation income to households and its salience under special circumstances in Mara. 
Diversification is clearly occurring widely across Maasailand but is not necessarily profitable. Non-livestock income presents a potentially positive investment option for the better-off able to access high-quality, well-watered farmland, or relatively highpaying jobs, or to intensify their livestock production. For the poorest families, nonlivestock income represents the only means to achieve food security and the only hope of rebuilding the herd. In practice, however, returns to marginal agriculture, irregular unskilled work and petty trade are so low that these households end up drawing down on their assets rather than building them up. Such poverty is distributed across livelihood strategies: there is no clear combination of activities that does best economically in any given set of circumstances (Homewood et al. 2009).

A recent analysis of livelihoods in the northern Kenya rangelands plots the position of households on the two axes of livestock holdings and cash income (McPeak et al. 2012). According to which quadrant they fall in, households are seen as 'left behind' (with below average holdings and cash income), 'staying' (as pastoralists, with above average livestock holdings but below average cash income), 'moving out' (from pastoralism, with below average livestock holdings and above average cash income) or as successfully 'combining' (pastoralism with other activities, above average for both livestock holdings and cash income). The present analysis seeks to go beyond this by looking in more detail at the relative contributions of individual activities to livelihoods, at the ways these combine to produce livelihood strategies, and at the role of wildlife-based revenues within these strategies.

These findings first highlight the lasting importance of livestock to Maasai households. Livestock remain central to subsistence, to pathways out of poverty and to wealth storage/accumulation strategies, alongside people's need or strategic choices to diversify into non-livestock activities. If we were to consider the social importance of livestock in maintaining social relations and not just their economic value, their significance would be all the greater. This absolutely central economic and livelihood importance of livestock is consistent with findings in the northern Kenya/southern Ethiopia pastoral rangelands (McPeak et al. 2012). The crucial importance of livestock production in these ASALs for both national economy and local livelihoods remains unacknowledged by most government policies in Kenya and more particularly in Tanzania, and also by many conservation interventions (WISP-IUCN 2007; Behnke and Muthami 2011).

Second, cultivation is widely practised but gives very limited returns. Besides adding to food security, it may be a tenure strategy, curbing land-grabbing (Zoomers 2010; Igoe 2007), including what is perceived locally as hostile encroachment of conservation on customary rangelands (Sachedina 2008).

Third, off-farm income is a very significant component of present-day Maasai livelihoods, usually more so than agriculture, but ranges from poorly paid, insecure, often dangerous work (miners, watchmen, sex workers) to secure jobs with wider political/ economic prospects (teachers, MPs).

Fourth, these results suggest that communities portrayed by some as the wealthiest land- and stock-owners in East Africa (Norton-Griffiths and Said 2010) have average incomes far below the dollar-per-day international poverty line and often below national rural poverty thresholds too. Given that these average income values are skewed upwards by a small number of well-off households (Homewood et al. 2009), and 
median incomes are in most cases around half mean values, poverty remains both wide and deep in Maasai rangelands despite potential land values and tourism earnings (Table 3). The mean and median incomes we documented broadly overlap but in some cases exceed the ranges of incomes in the northern Kenya/southern Ethiopia rangelands, mostly similarly below poverty line (Little et al. 2001)

Last but not least, wildlife generally performs poorly for livelihoods. With the exception of Mara, wildlife brings little or nothing to the vast majority of Maasai. If wildlife does not become locally valuable, it may continue to decline (Norton-Griffiths 2007; Norton-Griffiths and Said 2010; Ogutu et al. 2011).

Why does such a potentially profitable enterprise bring so little local benefit? These communities have historically captured little of total tourism earnings, with approximately 95\% accruing to tour operators, service industry workers, and the state (Norton-Griffiths 2007; Norton-Griffiths et al. 2008; Norton-Griffiths and Said 2010). The small amounts captured are then poorly distributed (Homewood and Thompson 2010). Proportions captured by local residents are even lower in Tanzania (Sachedina 2008) as they trickle through official channels, top-sliced at each stage from central and district governments through to the communal level via WMAs.

In part, this reflects chronic problems of governance and accountability at local, district and national levels e.g. (Walpole and Leader-Williams 2001; Sinclair et al. 2008; Homewood 2009; Bedelian in press). In Tanzania, wildlife enterprises earned tens of thousands of dollars annually for one village on the edge of Tarangire, and yet these revenues were easily dominated by local elites (Sachedina 2008). Ololosokwan village, situated east of Serengeti, was able, briefly, to earn around $\$ 50,000 /$ year from photographic safari operator use of its lands. However, the central government feared that this arrangement would conflict with a hunting block whose revenues they control. In November 2007, a surprise ministerial declaration criminalised local-level deals for wildlife-related enterprises, capturing all such returns for the state, with no requirement for a set proportion to be returned to the community (TNRF 2007). Such unequal contests between state and local communities for control of conservation enterprises and their returns have become a common occurrence in Tanzania (Nelson 2004; Nelson 2007; Baldus 2009). They are made the more unequal by the involvement of global investors (Igoe 2007). In their comparative study of community-based conservation, Nelson and Agrawal (2008) observe that the hunting industry in Tanzania is eminently corruptible, providing easily diverted revenues within a generally impoverished national economy.

Another reason is the historical experience of many Maa-speaking pastoralists. Conservation, for them, is associated with large-scale eviction and exclusion (from Serengeti,

Table 3 Mean value of total annual gross income in US dollars per household per year ( \pm standard deviation)

\begin{tabular}{llllll}
\hline Total gross income & Kitengela & Amboseli & Mara & Longido & $\begin{array}{l}\text { Tarangire } \\
(\mathbf{N = 2 6 )}\end{array}$ \\
\hline \$/household/year & $2,511 \pm 2,497$ & $1,583 \pm 1,655$ & $2,625 \pm 2,892$ & $733 \pm 1,518$ & $2,317 \pm 2,150$ \\
\$/AE/year & $453 \pm 445$ & $178 \pm 186$ & $474 \pm 563$ & $74 \pm 107$ & $403 \pm 380$ \\
\$/AE/day & 1.24 & 0.49 & 1.29 & 0.20 & 1.10 \\
\$/person/day & 1.78 & 0.48 & 0.84 & 0.16 & 0.85 \\
\hline
\end{tabular}

$A E$ adult equivalent; ${ }^{a}$ Kenya's official poverty line is Kshs $1,239 /$ month (CBS 2003; equivalent to $\$ 0.53 /$ person/day). 
Ngorongoro, Tarangire, Amboseli, Mkomazi; Figure 1) with fines and harassment, compromises and deals that were not honoured and outreach programmes providing few tangible benefits (Brockington 2002). Their experience of new revenue-sharing initiatives is rarely positive, and where it could be (as in some emerging conservancy agreements around Mara) distributional and knock-on effects of displacement are only just beginning to register. The livelihood choices that Maasai face now are shaped by decades of such experiences, perceptions and stories, as well as by complex communal politics, making it hard to build trust and cooperation (West et al. 2006; Adams and Hutton 2007).

A third reason has resulted from the efforts of the conservation lobby itself. The growing financial success of the African Wildlife Foundation went hand in hand with its growing out of touch with dilemmas in Maasai villages (Sachedina 2008, Sachedina 2010). This meant that it was poorly equipped to engage effectively with the fierce local politics that surround conservation initiatives in this region. Engaging with communities with such a record is an extremely difficult task.

Finally, these conservation enterprises have been given tremendous publicity, portrayed by their advocates as win-wins, good for wildlife, good for people, good for the economy, participatory, empowering and liberating (Igoe et al. 2010). Yet, there are few robust and in-depth evaluations of these initiatives, and where they have been examined in detail, these schemes rarely produce the benefits they claim. Once returns are divided up among the total population concerned, apparently high aggregate sums allocated to communities soon become insignificant as one-off payments. Moreover, distribution may often be highly inequitable. As this paper underlines, revenues from wildlife rarely begin to compensate for loss of mobility, access to and control over important natural resources, which 'community-based' and other conservation restrictions entail. Even relatively successful schemes produce thoroughly dissatisfied groups marginalised from the lucrative revenue streams flowing past them (Il Ngwesi, Kenya; Castillo 2004). Tanzanian WMAs in Burunge (west of Tarangire; Igoe and Croucher 2007), Longido (Homewood et al. 2005; Chenevix Trench et al. 2009) and elsewhere in Maasailand (Nelson et al. 2009) have restricted the use of the villages' grazing lands while removing their right to control returns or else have caused local displacement and eviction. Yet, conservation business is booming in East Africa; wildlife-based tourism remains a big earner for some, and analysis of the great majority of conservation NGOs in sub-Saharan Africa confirms their promotion of wildlife-based tourism as a money earner or source of significant investment (Brockington and Scholfield 2010).

This is an arena where considerable profits can be made precisely because the distribution of revenues is so uneven, and local and national governments are so easily compliant. However, circumstances are hardly conducive to mutually beneficial relationships sought by conservationists, governments and development organisations, nor ultimately to either the sustained recovery of currently dwindling wildlife populations, or the alleviation of wide and deep poverty.

The prospects are not good. In Kenya, the draft National Land policy set out innovative and socially equalising reforms which have come up against vociferous challenge by vested interests (MoL 2007a, b; Homewood 2009). Remaining areas of communal land are under threat from privatisation and/or state capture (Norton-Griffiths, personal communication). The Wildlife Bill 2007 (MTW 2007) proposes command and control of wildlife-related activities on private land. Private conservancies buy out some 
pastoralist landowners and establish set-aside agreements with others (Thompson et al. 2009; Bedelian in press). The extent to which they work for people on the one hand and wildlife on the other remain to be shown.

In Tanzania, the situation is still more alarming. A strong anti-pastoral environmentalism pervades the country, driving evictions from Usangu in 2007, in which people died, removals from Loliondo, a resumption of attempts to evict pastoralists from the joint land use area of the Ngorongoro Conservation Area and large-scale confiscations and fines in Kilosa and Mbarali. Meanwhile, the Tanzanian state commitment to conservation was applauded by US politicians and their sponsors at the International Conservation Caucus Foundation in Washington DC before the Serengeti Road issue surfaced; (Homewood et al. 2010). These are not incentives likely to make conservation-based enterprises work for Maasai communities in Tanzania. The short-sighted and self-defeating way in which Tanzania has implemented 'community conservation' has been severely criticised by one of the most experienced conservation practitioners in the field (Baldus 2009).

The fact remains that there are underexplored synergies between pastoralism and wildlife. Their shared interests in maintaining open rangelands and the possibility of mobile, migratory use of grazing and water resources could underpin not only biodiversity gains, but also adaptive responses to climate change (Davies and Nori 2008). That climate change may further constrain the already risky cultivation that has spread in these arid and semi-arid rangelands, driven by poverty on the one hand and commercial possibilities on the other. Conversely, allowing policies and practices which further erode open rangeland and mobility entails inevitable losses both to livestock production, which is of central importance to livelihoods, and to wildlife, which is of crucial significance to biodiversity and also to any potential that tourism may hold for economic growth and poverty alleviation. Positive developments in the management of wildlife-based revenues and project governance in areas like the MMNR may be emerging just in time to curb further declines in wildlife. However, the absence of wildlife benefits across the broader landscape, and their failure to flow to the broader array of non-landowning pastoral households, is driving the persistence of poverty. This suggests that the East African rangelands continue to move away from rather than returning to the spectacular coexistence of wildlife and pastoralism they sustained for the past millennia. Coexistence remains a possibility. There is a real role here for international conservation agencies. They need to use maximum integrity, skill and awareness to encourage the state to foster policies and practices that can genuinely bring benefits to local poor people, as well as to international conservation, and truly foster coexistence. The first stage in doing so will involve honest recognition of the real effects of the current policy and practice.

\section{Endnotes}

${ }^{\mathrm{i}}$ Without detailing all those involved in data collection and analysis, lead researchers included (besides $\mathrm{KH}$ and PCT) David Nkedianye and Patti Kristjanson (Kitengela); Michael Thompson (Mara); Shauna BurnSilver (Amboseli); and Hassan Sachedina (Tarangire). See Homewood et al. 2009 for full details.

${ }^{i i}$ The last decades have seen repeated wars in pastoralist areas of Ethiopia, Somalia and southern Sudan. These conflicts are well documented as having flooded East Africa with modern weaponry currently used in predatory raids on (and between) northern Kenyan, southern Ethiopian and northern Ugandan pastoralist groups. In 1978 and 
1979, Tanzania and Uganda were at war in the Kagera area, which is primarily pastoralist rangeland. At the time of writing, Kenya is formally at war with Somalia, in areas primarily used by pastoralists. Besides formal declarations of war, Kenyan and Tanzanian militaries joined forces during the 1990s to eliminate bandit groups moving from Kenya into northern Tanzania and reportedly massacring villagers in Loliondo and Ngorongoro Districts (e.g. Daily News 3.11.1998 as cited in Olajammi 2006). Violent conflict and outright war continue to impact on pastoralist livelihoods across sub-Saharan Africa in general and East Africa in particular.

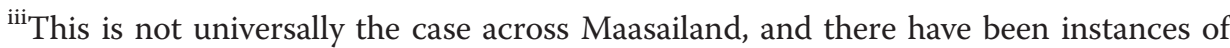
community-based tourism resulting in meaningful revenues that were then well distributed (Nelson and Makko 2003).

${ }^{\text {iv }}$ This paper does not go into the process of privatisation, which dispossessed many vulnerable families (Galaty 1999) but focuses on the impact of conservation business on current, mostly landowning residents.

${ }^{v}$ Households which were not able to secure claim to a private plot have been excluded not only from the possibility of such wildlife income, but also from the landscape as a whole (Galaty 1999). By definition, they cannot appear in our sample.

${ }^{\mathrm{vi}}$ Tarangire data do not allow for direct comparison.

\section{Abbreviations}

AE: Adult equivalent; CBC: Community-based conservation; KILA: Kitengela landowners' association; MMNR: Maasai Mara National Reserve; NCA: Ngorongoro conservation area; NP: National park; NR: National reserve; TLU: Tropical livestock unit; WMA: Wildlife management area.

\section{Competing interests}

The authors declare that they have no competing interests.

\section{Authors' contributions}

This paper represents a synthesis and discussion built on findings from individual studies whose principal researchers are listed in the acknowledgements below, with full details of all involved given in Homewood, Kristjanson and Chenevix Trench 2009. KH drew out the main conceptual findings from the underlying studies and drafted the present paper. PCT managed data, comparative analyses and improved the paper. KH, PCT and DB all contributed to interpretation and intellectual content and worked together to produce the final draft. All authors read and approved the final manuscript.

\section{Acknowledgements}

This paper draws on material and insights from individual studies by Shauna BurnSilver, Michael Thompson, David Nkedianye, Hassan Sachedina, Dickson Ole Kaelo, Patti Kristjanson, Maren Radeny, Fred Nelson, Stephen Kiruswa, Susanne Serneels, Mario Herrero and others, published in detail in Homewood, Kristjanson and Chenevix Trench 2009. We are grateful to all who collaborated in that work, to the many Maasai households who discussed their livelihoods with the researchers, to the Kenya and Tanzania governments who gave permission for the original fieldwork, and to the Belgian government DGIC fund who made possible the original collaborative work in drawing together these individual studies. A brief preliminary version of this paper was presented at the 2009 Zoological Society of London symposium on Biodiversity conservation and Poverty reduction, and published as Pastoralism and conservation: who benefits? In Roe et al. (in press).

\section{Author details}

${ }^{1}$ Anthropology, University College London, Gower Street, London WC1E 6BT, UK. ${ }^{2}$ Markets Trade and Institutions Division, International Food Policy Research Institute, 2033 K Street, NW, Washington, DC 20016, USA. ${ }^{3}$ Institute for Development Policy and Management, School of Environment and Development, The University of Manchester, Oxford Road, Manchester M13 9PL, UK.

Received: 14 October 2011 Accepted: 27 February 2012

Published: 28 September 2012

\section{References}

Adams, W, and J Hutton. 2007. People, parks and poverty: political ecology and biodiversity conservation. Conservation and Society 5(2): 147-183.

AWF. 2005. Kilimanjaro heartlands: a summary of AWF's engagement and related GIS data. African Wildlife Foundation Presentation given at ILRI Reto-e-Reto conference. January 2005.

Baldus, R. 2009. A practical summary of experiences after three decades of community-based wildlife conservation in Africa "What are the lessons learnt?" Budapest: FAO and CIC. 
Bedelian, C. in press. Conservancy land leases in the Mara, Kenya. Nairobi: LDPI working paper.

Behnke, R, and D Muthami. 2011. The contribution of livestock to the Kenyan economy. IGAD LPI Working Paper No. 03-11. Intergovernmental authority for development in Eastern Africa. Ababa: IGAD LPI Communications Office.

Bishop, E. 2007. Schooling and pastoralists' livelihoods: a Tanzanian case study. London: University College London. Unpublished PhD thesis.

Boku, T. 2008. Pastoralism under stress: resources, institutions and poverty among the Borana Oromo in Southern Ethiopia. Norwegian University of Life Sciences. PhD thesis, Ås.

Boone, RB, KA Galvin, SB BurnSilver, PK Thornton, DS Ojima, and JR Jawson. 2011. Using coupled simulation models to link pastoral decision making and ecosystem services. Ecology and Society 16(2): 6.

Brockington, D. 2002. Fortress conservation: the preservation of the Mkomazi Game Reserve. Oxford: James Currey Publishers.

Brockington, D. 2006. The politics and ethnography of environmentalisms in Tanzania. African Affairs 105(418): 97-116.

Brockington, D, and K Scholfield. 2010. Conservation NGOs and the conservationist mode of production in sub-Saharan Africa. Antipode 42(3): 551-575.

Bryceson, DF, and V Jamal. 1997. Farewell to farms: de-agrarianisation and employment in Africa. Aldershot: Ashgate

BurnSilver, S. 2009. Pathways of continuity and change: Maasai livelihoods in Amboseli, Kajiado District, Kenya. In Staying Maasai? Livelihoods, Conservation and Development in East African Rangelands, ed. K Homewood, P Kristjanson, and P Chenevix Trench, 161-208. New York: Springer.

Castillo, AR. 2004. Sustainable inequalities? Community-based conservation in an 'inequitable society'. The case of II Ngwesi Group Ranch, Kenya. Masters Thesis. Oxford: University of Oxford.

CBS. 2003. Annual facts and figures. Government of Kenya, Nairobi (now Kenyan National Central Bureau of Statistics KNBS): Central Bureau of Statistics.

Chenevix Trench, P, S Kiruswa, F Nelson, and K Homewood. 2009. Still people of cattle? Livelihoods, diversification, and community conservation in Longido District. In Staying Maasai? Livelihoods, Conservation and Development in East African Rangelands, ed. K Homewood, P Kristjanson, and P Chenevix Trench, 217-256. New York: Springer.

Davies, J, and M Nori. 2008. Managing and mitigating climate change through pastoralism. IUCN Commission on Environmental, Economic and Social Policy: Policy Matters. http://cmsdata.iucn.org/downloads/policy_matters_16. pdf Accessed 14 March 2012.

Dietz, T, AA Nunow, AW Roba, and F Zaal. 2001. Pastoral commercialisation: on caloric terms of trade and related issues. In African Pastoralism: Conflict, Institutions and Government, ed. MA Salih, T Dietz, and AGM Ahmed, 194-234. London/SterlingVirginia: Pluto Press/OSSREA.

Galaty, J. 1999. Grounding pastoralists: law, politics and dispossession in East Africa. Nomadic Peoples 3(2): 56-73.

Galvin, KA. 2009. Transitions: pastoralists living with change. Annual Review of Anthropology 38(1): 185-198.

Georgiadis, N, F Ihwagi, JGN Olwero, and S Romanach. 2007. Savanna herbivore dynamics in a livestock-dominated landscape. II. Ecological, conservation, and management implications of predator restoration. Biological Conservation 137: 473-483.

Homewood, K. 2008. Ecology of African pastoralist societies. Oxford: James Currey and Ohio UP.

Homewood, K. 2009. In Staying Maasai? Livelihoods, Conservation and Development in East African Rangelands, ed. K Homewood, P Kristjanson, and P Chenevix Trench, 335-368. New York: Springer.

Homewood, K, and M Thompson. 2010. Social and economic challenges to conservation in East African rangelands: land use, livelihoods and wildlife change in Maasailand. In Wild Rangelands: Conserving Wildlife While Maintaining Livestock in Semi-arid Ecosystems, ed. J Deutsch, J Du Toit, and R Kock, 340-366. Oxford: Wiley Blackwell.

Homewood, K, E Lambin, E Coast, A Kariuki, I Kikula, J Kivelia, M Said, S Serneels, and M Thompson. 2001. Long-term changes in Serengeti-Mara wildebeest and land cover: pastoralism, population or policies? Proceedings of the National Academy of Sciences 98(22): 12544-12549.

Homewood, K, M Thompson, PC Trench, S Kiruswa, and E Coast. 2005. Community- and state-based natural resource management and local livelihoods in Maasailand. Gestione della risorse naturali su base communitaria e statale. Ambiente e sviluppo sostenibile in Africa australe. Special issue on community-based natural resource management. Afriche e Orienti 2005(2): 84-101.

Homewood, K, P Trench, S Randall, L Lynen, and E Bishop. 2006. Impacts of a veterinary intervention in Maasai Cattle: livestock health, socio-economic correlates and ecological implications. The infection-and-treatment vaccine against East Coast fever. Agricultural Systems 89: 248-71.

Homewood, K, P Kristjansen, and P Chenevix Trench (eds.). 2009. Staying Maasai? Livelihoods, Conservation and Development in East African Rangelands. New York: Springer.

Homewood, K, D Brockington, and S Sullivan. 2010. Alternative view of Serengeti road. Nature 467: 788-789.

Hutton, J, W Adams, and J Murombedzi. 2005. Back to the Barriers? Changing narratives in biodiversity conservation. Forum for Development Studies 2: 341-370.

Igoe, J. 2007. Human rights, conservation and the privatization of sovereignty in Africa - a discussion of recent changes in Tanzania. Policy Matters 15: 241-254.

Igoe, J, and B Croucher. 2007. Conservation, commerce, and communities: the story of community-based wildlife management areas in Tanzania's northern tourist circuit. Conservation and Society 5(4): 534-561.

Igoe, J, K Neves, and D Brockington. 2010. A spectacular eco-tour around the historic bloc: theorizing the current convergence of conservation and capitalism. Antipode 42(3): 486-512.

Iliya, M, and K Swindell. 1997. Winners and losers: household fortunes in the urban peripheries of Northern Nigeria. In Farewell to Farms. De-agrarianisation and Employment in Africa, ed. D Bryceson and V Jamal, 85-100. Aldershot: Ashgate.

Lambin, EF, and P Meyfroidt. 2011. Global land use change, economic globalization, and the looming land scarcity. Proceedings of the National Academy of Sciences (PNAS) early edition 108: 3465-3472. 10.1073/pnas.1100480108.

Lamprey, RH, and RS Reid. 2004. Expansion of human settlement in Kenya's Maasai Mara: what future for pastoralism and wildlife? Journal of Biogeography 31(6): 997-1032.

Lewa Wildlife Conservancy. 2010. Lewa wildlife conservancy: a catalyst for conservation. http://www.lewa.org Accessed 14 March 2012. 
Little, P. 2003. Somalia: economy without a State. Oxford: James Currey.

Little, PD, K Smith, BA Cellarius, D Layne Coppock, and CB Barrett. 2001. Avoiding disaster: diversification and risk management among East African herders. Development and Change 32(3): 401-433.

Mace, R. 1993. Transitions between cultivation and pastoralism in sub-Saharan Africa. Current Anthropology 34(4): 363-381.

Mace, G, H Masundire, and J Baillie. 2005. Biodiversity. In Ecosystems and Human Well-being: Current State and Trends: Findings of the Condition and Trends Working Group (millennium ecosystem assessment series), ed. G Ceballos, S Lavorel, G Orians, and S Pacala, 74-115. Washington, D.C.: Island Press.

McPeak, J, and P Little (eds.). 2006. Pastoral livestock marketing in Eastern Africa: research and policy challenges. London: Intermediate Technology Publications.

McPeak, J, P Little, and C Doss. 2012. Risk and social change in an African rural economy: livelihoods in pastoral communities. London: Routledge.

Milliken, T, R Emslie, and B Talukdar. 2009. African and Asian rhinoceroses - status, conservation and trade. CoP15 Doc. 45.1 Annex. http://www.cites.org/common/cop/15/doc/E15-45-01A.pdf. Accessed 14 March 2012.

Ministry of Tourism. 2010. Facts and figures. http://www.tourism.go.ke/ministry.nsf/pages/facts_figures Accessed 14 March 2012.

Ministry of Tourism and Wildlife, Republic of Kenya. 2006. Statistical analysis of tourism trends. Central planning Unit. http://www.tourism.go.ke/ministry.nsf/doc/Tourism_Trends_OCT2006_Revised.pdf Accessed November 2008.

MoL. 2007a. Draft national land policy. National land policy secretariat, 61. Nairobi: Ministry of Lands.

MoL. 2007b. National land policy: the formulation process. National land policy secretariat. Nairobi: Ministry of Lands and Daily Nation.

MoLF. 2006. Draft national livestock policy. Nairobi: Ministry of Livestock and Fisheries Development.

MTW. 2007. Draft wildlife bill 2007. Nairobi: Ministry of Tourism and Wildlife.

Nelson, F. 2004. The evolution and impacts of community-based ecotourism in northern Tanzania. Drylands issue paper no. 131. London: IIED.

Nelson, F. 2007. Emergent or illusory? Community management in Tanzania. IIED issues paper no. 146: 1-32.

Nelson, F, and A Agrawal. 2008. Patronage or participation? Community-based natural resource management reform in sub-Saharan Africa. Development and Change 39(4): 557-585.

Nelson, F, and S Makko. 2003. Communities, conservation and conflicts in the Tanzanian Serengeti. Savannah Georgia: Proceedings of the third annual community-based conservation network seminar: turning natural resources into assets.

Nelson, F, B Gardiner, J Igoe, and A Williams. 2009. Community-based conservation and Maasai livelihoods in Tanzania. In Staying Maasai? Livelihoods, Conservation and Development in East African Rangelands, ed. K Homewood, P Kristjansen, and P Chenevix Trench, 299-333. New York: Springer.

Nkedianye, D, M Radeny, P Kristjanson, and M Herrero. 2009. Assessing returns to land and changing livelihood strategies in Kitengela. In Staying Maasai? Livelihoods, Conservation and Development in East African Rangelands, ed. K Homewood, P Kristjansen, and P Chenevix Trench, 115-149. New York: Springer.

Norton-Griffiths, M. 2007. How many wildebeest do you need? World Economics 8(2): 41-64.

Norton-Griffiths, M, and M Said. 2010. The future for wild life on Kenya's rangelands: an economic perspective. In Wild Rangelands: Conserving Wildlife While Maintaining Livestock in Semi-arid Ecosystems, ed. J Deutsch, J Du Toit, and R Kock, 367-392. Chichester: Wiley Blackwell.

Norton-Griffiths, M, M Said, S Serneels, D Kaelo, M Coughenour, R Lamprey, M Thompson, and R Reid. 2008. Land-use economics in the Mara area of the Serengeti ecosystem. In Serengeti III: Human Impacts on Ecosystem Dynamics, ed. ARE Sinclair, C Packer, S Mduma, and J Fryxell, 379-426. Chicago: Chicago University Press.

Ogutu, J, N Owen-Smith, H-P Piepho, and M Said. 2011. Continuing wildlife population declines and range contraction in the Mara region of Kenya during 1977-2009. J Zoology. 285: 99-109.

Olajammi, S. 2006. Contested lands: land disputes in semi-arid parts of Northern Tanzania: case studies of the Loliondo and Sale divisions in the Ngorongoro District. Doctoral dissertation: University of Helsinki.

Ottichilo, W, J de Leeuw, A Skidmore, H Prins, and M Said. 2001. Population trends of large non - migratory wild herbivores and livestock in the Masai Mara ecosystem, Kenya, between 1977 and 1997. African Journal of Ecology 38: 202-216.

Oxfam. 2002. Milking the CAP: how Europe's dairy regime is devastating livelihoods in the developing world. Washington: Oxfam International.

Oxfam. 2006. Delivering the agenda: addressing chronic under-development in Kenya's arid lands. Oxfam International Briefing Paper, May 2006.

Pearce, D, and D Moran. 1994. The economic value of biodiversity. London: Earthscan.

Roe, D, M Walpole, and J Elliott. 2999. Linking Biodiversity Conservation and Poverty Reduction. Wiley-Blackwell. Conservation Science and Practice series. in press.

Sachedina, H. 2008. Wildlife is our oil: conservation, livelihoods and NGOs in the Tarangire ecosystem. Unpublished PhD thesis, University of Oxford.

Sachedina, H. 2010. Disconnected nature: the scaling up of African Wildlife Foundation and its impacts on biodiversity conservation and local livelihoods. Antipode 42(3): 603-623.

Sachedina, H, and P Chenevix Trench. 2009. Staying Maasai? Livelihoods, Conservation and Development in East African Rangelands. In Cattle and crops, tourism and Tanzanaite: poverty, land use change and conservation in Simanjiro District, Tanzania, ed. K Homewood, P Kristjanson, and P Chenevix Trench, 263-298. New York: Springer.

Sandford, S. 2006. Foreword in: pastoral livestock marketing in Eastern Africa: research and policy challenges, eds. $J$ McPeak and P Little. Warwickshire: ITDG Publishing.

Scholfield, K, and D Brockington. 2009. Non-governmental organisations and African wildlife conservation: a preliminary analysis. BWPI working paper 80. Newcastle and Manchester Universities. http://www.bwpi.manchester.ac.uk/ resources/Working-Papers/bwpi-wp-8009.pdf.

Sellen, DW. 2003. Nutritional consequences of wealth differentials in east African pastoralists: the case of the Datoga of northern Tanzania. Human Ecology 31(4): 529-570. 
Serneels, S, M Herrero, S BurnSilver, P Chenevix Trench, K Cochrane, K Homewood, P Kristjanson, F Nelson, M Radeny, M Thompson, and M Said. 2009. Methods in the analysis of Maasai livelihoods. In Staying Maasai? Livelihoods, Conservation and Development in East African Rangelands, ed. K Homewood, P Kristjanson, and P Chenevix Trench, 43-68. New York: Springer.

Sikana, P, C Kerven, and R Behnke. 1993. From subsistence to specialised commodity production: commercialisation and pastoral dairying in Africa, pastoral development network 34: 1-46. London: Overseas Development Institute.

Sinclair, ARE, C Packer, S Mduma, and J Fryxell. 2008. Serengeti III: human impacts on ecosystem dynamics. Chicago: Chicago University Press.

Stoner, C, T Caro, S Mduma, C Mlingwa, G Sabuni, and M Borner. 2007. Assessment of effectiveness of protection strategies in Tanzania based on a decade of survey data for large herbivores. Conservation Biology 21: 635-646.

Swift, J. 1986. The economics of production and exchange. In Pastoralists of the west African Savanna, ed. M Adamu and A Kirk-Greene, 175-190. Manchester: Manchester University Press.

Tenga, R, A Mattee, N Mdoe, R Mnenwa, S Mvungi, and M Walsh. 2008. A study on the options for pastoralists to secure their livelihoods in Tanzania. CORDS, PWC, IIED, MMM Ngaramtoni, TNRF, UCRT. http://www.tnrf.org/node/ 7487. Accessed 14 March 2012.

The Economist. 1993. The fat of the land: made in Europe, dumped in Africa.

The Tanzania National Website. 2009. The economic survey 2009. http://www.tanzania.go.tz/economicsurveyf.html, page 139. Accessed 14 March 2012.

Thompson, DM, and K Homewood. 2002. Elites, entrepreneurs and exclusion in Maasailand. Human Ecology 30: 107-138.

Thompson, M, S Serneels, and EF Lambin. 2002. Land-use strategies in the Mara ecosystem (Kenya): a spatial analysis linking socio-economic data with landscape variables. In Linking People, Place and Policy: a GIScience Approach, ed. SJ Walsh and KA Crews-Meyer. Boston: Kluwer Academic Publishers.

Thompson, M, S Serneels, D Ole Kaelo, and P Chenevix Trench. 2009. Maasai Mara - land privatization and wildlife decline: can conservation pay its way? In Staying Maasai? Livelihoods, Conservation and Development in East African Rangelands, ed. K Homewood, P Kristjanson, and P Chenevix Trench, 77-114. New York: Springer.

Thornton, P, S BurnSilver, R Boone, and K Galvin. 2006. Modeling the impacts of group ranch subdivision on agro-pastoral households in Kajiado, Kenya. Agricultural Systems 87: 331-356.

TNRF. 2007. New regulations signed for all non-consumptive wildlife use in game reserves and village lands. Tanzania Natural Resources Forum. http://www.tnrf.org/node/6529. Accessed 14 March 2012.

UNDP/UNEP/IED/IUCN/WRI. 2005. Environment for the MDGs. A message to the World Summit. Sustaining the environment to fight poverty and achieve the MDGs: the economic case and priorities for action. New York: UNDP http://www.povertyenvironment.net/pep. Accessed 14 March 2012.

URT. 1997. Livestock and agriculture policy. Section 3: soil conservation and land use planning. pp 55-68. Section 4: range management pp127-131. Dar es Salaam, Tanzania: Policy statements, United Republic of Tanzania.

URT. 2002. The United Republic Of Tanzania Ministry Of Natural Resources and Tourism. Tourism master plan: strategy and actions. http://www.tzonline.org/pdf/tourismmasterplan.pdf Accessed 14 March 2012.

URT. 2005. Mkukuta: Tanzania's national strategy for growth and reduction of poverty. Vice-President's Office: United Republic of Tanzania.

Walpole, MJ, and N Leader-Williams. 2001. Masai Mara tourism reveals partnership benefits. Nature 413: 771.

West, P, J Igoe, and D Brockington. 2006. Parks and peoples: the social impact of protected areas. Annual Review of Anthropology 35: 14.1-14.27.

Western, D, S Russell, and K Mutu. 2006. The status of wildlife in Kenya's protected and non-protected areas. Paper commissioned by Kenya's wild life policy and legislation review. Nairobi: African Conservation Centre.

Western, D, S Russell, and I Cuthill. 2009. The status of wild life in protected areas compared to non-protected areas of Kenya. PloS One 4(7): e6140. doi:10.1371/journal.pone.0006140.

WISP-IUCN. 2007. Global review of the economics of pastoralism. http://data.iucn.org/wisp/documents_english/ global_review_ofthe_economicsof_pastoralism_en.pdf Accessed 14 March 2012.

Zaal, F, and T Dietz. 1999. Of markets, meat, maize and milk: pastoral commoditisation in Kenya. In The poor are not us, ed. D Anderson and V Broch-Due, 163-194. Oxford: James Currey.

Zaal, F, M Ole Siloma, R Andiema, and A Kotomei. 2006. The geography of integration: cross-border livestock trade in East Africa. In Pastoral Livestock Marketing in Eastern Africa. Research and Policy Challenges, ed. J McPeak and P Little, 145-168. London: Intermediate Technology Publications.

Zoomers, A. 2010. Globalisation and the formalisation of space: seven processes driving the current global land grab. Journal of Peasant Studies 37(2): 429-447.

doi:10.1186/2041-7136-2-19

Cite this article as: Homewood et al:: Pastoralist livelihoods and wildlife revenues in East Africa: a case for coexistence? Pastoralism: Research, Policy and Practice 2012 2:19. 